\title{
Alcohol Rehabilitation: A Proposal Based on Partecipation and Empowerment
}

\author{
M. Manera, M.D. ${ }^{1}$, E. Colla ${ }^{2}$, R. Ferrucci, M.M.D. ${ }^{3}$, S. Parisi ${ }^{4}$, L. Pellegrini, M.D.D. ${ }^{5}$ \\ A. Giustini ${ }^{6}$, L. Liberto, M.M.D. ${ }^{7}$ \\ ${ }^{1}$ S. Pancrazio Hospital Alcohol Rehabilitation Unit Arco (TN) Italy. \\ ${ }^{2}$ Nurse Coordinator S. Pancrazio Hospital Alcohol Rehabilitation Unit Arco (TN) Italy. \\ ${ }^{3}$ Addictions Department, APSS Trento Italy. \\ ${ }^{4}$ Psychologist S. Pancrazio Hospital Alcohol Rehabilitation Unit Arco (TN) Italy. \\ ${ }^{5}$ Alcohology anti-smoking center and other fragility of Addictions Department APSS Trento Italy. \\ ${ }^{6}$ Scientific M.D.D. S. Pancrazio Hospital Arco (TN) Italy. \\ ${ }^{7}$ S. Pancrazio Hospital Alcohol Rehabilitation Unit Arco (TN) Italy. \\ michela.manera@ospedalesanpancrazio.it
}

The Alcohol Rehabilitation Unit of "San Pancrazio" Hospital, Arco, Trento, was created in the 1980's and is now the only alcoholic rehabilitation residence of it's kind in the state of Trentino.

From may 2016, due to hospital upgrades and reconstruction, the department was relocated in the neighboring building "Villa Garda " and has resulted in many positive outcomes as follows.

The staff are more efficient in their daily duties, more able to control the patients and manage the problems connected with multiple addiction, antisocial personalities, aggressive behavior, psychiatric disorders, impulsivity.

Our patients, however, benefit from a more adequate environment: the scientific data suggests that for these kinds of patents it is important to share a therapeutic-rehabilitative path within a group of similar needs, avoiding cases of misjudgment or feelings to be excluded.

The staff is made up of three doctors, two psychologists, in which one is a expressional therapist, a social assistant, a musical therapist, specialist nurses, OSS and physiotherapists.

Our program takes on multidimensional fragilities, which are symptoms of alcohol abuse, drug addiction, gambling addiction, smoking addiction, food disorders, psychiatric disorders, chronic mental health problems.

This is an intense intervention, which follows a three to six weeks rehabilitation, dependent of the patients needs. The program utilizes a proven integrated medical-psychological-social method.

The therapeutic-rehabilitative program is based around the thought that the addiction is a proven result of organic, psychological and interactional diseases found in the individuals psyche, family history and social environment. This is a global method of treatment based around the person, the family and personal environment.

The program guarantees a pharmacological detoxication and follows the needs in difficult situations of organic comorbidities with an increased reduction in the time frame of the diagnostic process assisted by the fact that the patient is drug free during the therapy. The program also guarantees a precise aftercare follow up.

The table below shows relative data from the years 2015-2018: 
Alcohol Rehabilitation: A Proposal Based on Partecipation and Empowerment

\begin{tabular}{|c|c|c|c|c|c|c|c|}
\hline & 2015 & \multicolumn{2}{|c|}{2016} & \multicolumn{2}{|c|}{2017} & \multicolumn{2}{|c|}{2018} \\
\hline Total patients & 422 & 429 & & 428 & & $41 \mathrm{c}$ & \\
\hline men & $295 \quad 69,9 \%$ & 309 & $72 \%$ & 290 & $69,8 \%$ & 295 & $70,4 \%$ \\
\hline women & $127 \quad 30,1 \%$ & 120 & $28 \%$ & 125 & $30,2 \%$ & 124 & $29,6 \%$ \\
\hline middle age & 50,96 & 52,2 & & 50 , & & 48 , & \\
\hline drop out & $12 \quad 2,8 \%$ & 14 & $3,2 \%$ & 18 & $4,2 \%$ & 20 & $4,77 \%$ \\
\hline re-entry & $93 \quad 22 \%$ & 106 & $24,7 \%$ & 99 & $23,1 \%$ & 99 & $23,6 \%$ \\
\hline
\end{tabular}

Over the years our department has constantly evolved to adapt to the requirements of the patients and the ever evolving complexity of their needs.

Therefore requiring an accurate understanding of all useful data to aid in the overall picture of the patients needs both family and social. The methods in which we gather information which is then utilized are : open family meetings and discussions, telephone conversations with Social Services, face to face meetings and discussions.

To territorial Services is required a pre-admission schedule, which explain personal data, clinical informations such as diseases, even if psychiatric illnesses, previous suicide attempts, relationships, relatives or care givers who can take parts at the actvities proposed to rehability and the aim of the sending.

The assestment of the motivations is for sure a very important data, but we consider that a person who has a very low motivation is just a person harder to help and than to bring in motivational progress with greater care. An accurate multidisciplinary assestment is done in order to locate and activate personal resources, but from families or friends too. At their arrive in hospital we compile an individual rehabilitation project, that report the clinical complexity, the aim proposed, the intervention to be implemented, the rehabilitation path end outcomes.

The improving of adaptive functioning, but even psychological, social and organic, is the aim of the rehabilitation. Indispensable is work on the relationship and our tools to achieve the goal are:

- a community environment, which repeats the complexity of external social dynamics, without excluding the difficulties of everyday life

- a rule sistem with educational purpose, with continuous control from the operators, in the 24 hours long, not just during the activities

-psycological support and social counselling, offered to the relatives too, to whom is required attendance during the group meetings.

Over the years there has been a progressive adaptation to the complexity of the users. Just thinking about the concept of multidimensionality of discomfort: the centrality of the intervention has been shifted from person to person with his family in the socio-relational context, expanding our vision and taking into consideration hardships and fragility that may affect one or more members of the family:

- losses (role, work, disease event)

- attachment (to substances, to behaviors)

- relational and social problems

- unhealthy life styles

and basing work on relationship and change.

So: what can / must offer rehabilitation: global acceptance that works with the whole family, so that patient 
must be an actor and not a passive subject, he must be helped to express their discomfort, to work on the relationship and on motivation for change and must be helped to make the most of their internal resources in order to restore a balance as stable as possible.

The family unit must be helped to express its hardships and needs, to work on the relationship and on the motivation to change. Another issue that we very much feel is the concept of " chronicity", which referred to people with a long history of dependence, with numerous failed rehabilitation attempts, which show no significant evolution in their lifestyle and care path, with few personal resources family, friends or network.

We have estimated that about $35 \%$ of users received each year have these characteristics, and the figure is increasing. We are convinced that rehabilitation should offer these people flexible care pathways, which can be modulated according to the current phase of change, and we believe that interventions may not be sequential. Minimum goals are acceptable. The priority of the interventions must be identified so that the person can achieve the highest possible level of functioning.

The theme of fragility is important, which in recent years has become central in various fields of medicine, such as geriatrics, cardiology ... Fragility can be defined as a condition of increased vulnerability in various areas (physical, mental, social) associated with an increased risk of negative outcomes.

Identifying a fragility index would allow us to assess the priority needs of our users, addressing in an appropriate way the type of interventions to be implemented. We could also measure the effectiveness of our rehabilitation intervention, giving evidence of the results obtained and transparency to our professional action. To this end we started working on this project, in collaboration with the territorial Services. Finally, a project that is about to start is the treatment of people who have problems with drug addiction or gambling, but not necessarily alcohol-related. The factor that will unite the members of the group is the need for change, which becomes the fundamental goal of therapeutic work. This objective will also be extended to the other members of the family unit. The program will be agreed with the territorial Services, deciding on operating methods, indicators and data to measure the effectiveness of the rehabilitation intervention

\section{REFERENCES}

1. Rapporti ISTISAN 16/4 2016 "EpidemiologiA E Monitoraggio alcol-correlato in Italia e nelle Regioni" a cura di E. Scafatoper il gruppo di lavoro CSDA

2. Agabio R., Pani P.P., Gessa G.L., Franconi F. (2016) "Efficacy of medications approved for the treatment of alcohol dependences and alcohol withdrawal syndrome in female patients. A descriptive review. European Addiction Research, 22:1-1

3. Cipolla C. (2013) Droghe al femminile, Franco Angeli, Milano

4. www.epicentro.iss.it, Piano Azione Europeo per ridurre il consumo dannoso di alcol 2012-2020

5. Zambon A., Soares Pinto S.P., Agostini D., Biondini F., Bizzi P., Dattola A., Forghieri M., Giorgi I., Girardi F., Hinnenthal I., Jaretti Sodano A., Liberto L., Majolino E., Mioni D., Movalli M., Pedretti L., Propato A., Ranalletti P., Spoalor G., Vizzuso P., Zucchi G., Vittadini G. "La residenzialità alcologica ospedaliera: caratteristiche dei pazienti e dei percorsi terapeutici/riabilitativi" Minerva Medica 2013 April; 104(2):193-206

6. Cibin M., Hinnenthal I. Il punto di vista del paziente come elemento diagnostico e terapeutico: la "rivoluzione motivazionale" in Comunità terapeutica. Medicina delle Dipendenze 2011; I:2

7. Hinnenthal I., Laki Z., Ardissone G. Psicotraumatologia e neuroplasticità. Presupposti teorici per la gestione clinica del trattamento residenziale di alcolisti con poliabuso. In: Lucchini A., Nava F., Manzato E. Buone pratiche e procedure terapeutiche nella gestione del paziente alcolista. Milano: Franco Angeli 2008. 
Alcohol Rehabilitation: A Proposal Based on Partecipation and Empowerment

8. Cibin M., Hinnenthal I., Lugato E. I programmi residenziali brevi. Medicina delle Tossicodipendenze 2009; 65:39_46

9. Morlatt G.A., Barrel K. La prevenzione delle ricadute. In: Galanter M., Kleber H.D. Trattamento dei disturbi da uso di sostanze. Milano: Edizioni Masson 1998

10. Berti A., Cocci V., Orsini C., Biagianti C., Cucinelli M.L., Marioli A., Benci S., Dimauro P., Cipriani F., Voller F. Il gioco d'azzardo patologico tra gli utenti dei Ser.T.: polidipendenze e comorbilità. Atti del $2^{\circ}$ Convegno Ass. Di Epidemiologia , Firenze 2008

11. Gunderson JG. La personalità borderline. Una guida clinica. Raffaello Cortina Ed. 2010

12. Caretti V., La Barbera D. Le dipendenze patologiche. Clinica e psicopatologia Raffaello Cortina Ed. 2005

13. Fanella F. Il trattamento terapeutico-riabilitativo della dipendenza patologica. Ed. Alpes 2011

14. Conte G., D’Alessandris L., Vasale M., Franza R., Fanella F., Righino E., Pettorruso M., Allegretti L., Tonioni F., (2012). Il trattamento del gioco d'azzardo patologico: studio preliminare di un modello terapeuticoriabilitativo di gruppo. Italian ournal on Addiction vol. 2 numero 3-4

15. Caneppele, S., \& Marchiaro, M. (2015). Gioco d'azzardo patologico: Monitoraggio e prevenzione in Trentino. Trento: Transcrime - Università degli Studi di Trento, 2015 (c) 1172015 Transcrime - Joint Research Centre on Transnational Crime, 229 Disponibile online presso[http://hdl.handle.net/10807/67277]

16. Ministero della Salute - CCM, Dipendenze comportamentali (2011). Gioco d'azzardo patologico: progetto sperimentale nazionale di sorveglianza e coordinamento/monitoraggio degli interventi - Regione Piemonte. Bollettino sulle Dipendenze, 34(1/2011)

17. Serpelloni, G., \& Rimondo, C. (2012). Gioco d'azzardo problematico e patologico: inquadramento generale, meccanismi fisiopatologici, vulnerabilità, evidenze scientifiche per la prevenzione, cura e riabilitazione. Italian Journal on Addiction,2(34), 7-44.

18. Tonazzolli E., Benvenuto A., (2016) Strategie di prevenzione del gioco d'azzardo patologico: progetti attuati in Trentino Alto-Adige. Disponibile on line: http://www.stateofmind.it/2016/07/gioco-dazzardopatologico-prevenzione- trentino/

Citation: M. Manera, M.D., E. Colla, R. Ferrucci, M.M.D., et al. “Alcohol Rehabilitation: A Proposal Based on Partecipation and Empowerment". American Research Journal of Addiction and Rehabilitation. 2019; 2(1): 1-4.

Copyright (c) 2019 M. Manera, M.D., E. Colla, R. Ferrucci, M.M.D., et al. This is an open access article distributed under the Creative Commons Attribution License, which permits unrestricted use, distribution, and reproduction in any medium, provided the original work is properly cited.

American Research Journal of Addiction and Rehabilitation

Page 4 